\title{
DAMPAK PENCEMARAN LINGKUNGAN LAUT TERHADAP INDONESIA AKIBAT TUMPAHAN MINYAK MONTARA DI LAUT TIMOR
}

\author{
Ni Putu Suci Meinarni \\ STIKI INDONESIA \\ Jalan Tukad Pakerisan No. 97 Denpasar \\ Email : sucimeinarni@gmail.com
}

\begin{abstract}
ABSTRAK
Dalam pembahasan tentang aturan internasional dan legislasi nasional untuk mencegah, mengurangi, dan mengendalikan pencemaran lingkungan laut, Pasal 207-212 UNCLOS 1982 menyebutkan secara khusus enam jenis pencemaran laut, yaitu: pencemaran dari sumber daratan, pencemaran dari aktivitas dasar laut yang termasuk dalam yurisdiksi nasional, pencemaran dari aktivitas dalam area terkait, pencemaran oleh dumping, pencemaran dari kapal, dan pencemaran dari atau melalui atmosfer.

Banyak negara yang melakukan eksploitasi berlebih, tanpa memperhatikan kelestarian laut dan sumber daya yang ada di dalamnya. Ditambah lagi, tindakantindakan pelestarian dan perlindungan lingkungan laut seringkali diabaikan dan tidak dilaksanakan secara optimal. Tindakan-tindakan semacam ini tidak hanya merugikan negara terkait, melainkan juga negara lain yang terletak di sekitar negara terkait. Lebih lanjut lagi, kondisi tersebut memicu terjadinya sengketa antara negara atau pihak yang disinyalir sebagai penyebab kerusakan atau pencemaran dengan negara atau pihak lain yang terkena imbas kerusakan atau pencemaran tersebut.

Menurut Pemerintah Republik Indonesia, Kasus Minyak Montara yang terjadi di Laut Timor juga berakibat pada wilayah perairan Indonesia khususnya di wilayah Provinsi Nusa Tenggara Timur. Hanya saja, PTTEP Australasia, berdasarkan partnership research dengan beberapa perguruan tinggi di Australia, menyatakan bahwa dampak dari Kasus Minyak Montara tidak menimbulkan dampak negatif ke wilayah perairan Indonesia.

Berdasarkan kesimpulan diatas, penulis dapat memberikan saran sebagai berikut : sebaiknya dibentuk suatu konvensi internasional atau aturan hukum internasional yang khusus berkaitan dengan pencemaran lingkungan laut akibat pengeboran minyak lepas pantai. Seperti contohnya MARPOLyang khusus mengatur mengenai pencemaran minyak dari
\end{abstract}

\section{Kata kunci : Pencemaran Lingkungan, Kasus Minyak Montara, Perairan Indonesia.}

ABSTRACT

In this discussion of the rules of international and national legislation to prevent, reduce and control pollution of the marine environment, Articles 207-212 of UNCLOS in 1982 specifically mention six types of marine pollution, namely: pollution from landbased sources, pollution from seabed activities within the jurisdiction of the national, pollution from activities in the area concerned, pollution by dumping, pollution from ships, and pollution from or through the atmosphere.

Many countries are doing excessive exploitation, without regard to the preservation of the sea and the resources in it. Moreover, measures of conservation and 
protection of the marine environment are often ignored and not implemented optimally. Such actions are not only detrimental to the countries concerned, but also other countries located around the country concerned. Furthermore, the condition causing disputes between states or parties pointed out as the cause of damage or contamination to the state or other party affected by damage or pollution.

According to the Government of the Republic of Indonesia, Montara Oil Cases that occurred in the Timor Sea has also resulted in the territorial waters of Indonesia, especially in the area of East Nusa Tenggara province. However, PTTEP Australasia, based on research partnerships with several universities in Australia, suggests that the impact of the Montara Oil case did not cause a negative impact to the territorial waters of Indonesia.

Based on the above conclusions, the author can give the following advice: should set up an international convention or rule of international law that specifically deals with pollution of the marine environment as a result of offshore oil drilling. For example MARPOLyang specifically regulating oil pollution from

\section{Keywords: Environmental Pollution, Oil Case Montara, Indonesian waters.}

\section{Pendahuluan}

Sebelum tahun 1960, permasalahan polusi laut kurang mendapat perhatian. Situasi ini kemudian berubah sejak terjadinya kecelakaan pada kapal tanker Torrey Canyon (1967), Amoco Cadiz milik Britania (1978), Exxon Valdez di Alaska (1989), dan Sea Empress milik Wales Barat Daya (1996) yang menyebabkan tumpahnya minyak mentah ke dalam laut. Peristiwa-peristiwa tersebut menggerakkan para pembuat kebijakan, legislator, dan masyarakat, untuk mengangkat permasalahan tentang pencemaran laut (Churchill;1999). Pencemaran laut akibat tumpahan minyak yang terjadi di perairan Indonesia akibat meledaknya ladang minyak PTTEP Australasia di Platform Montara telah memperoleh perhatian dari berbagai pihak baik dari masyarakat di pesisir laut timor, LSM Pemerhati Lingkungan, Pemerintah Republik Indonesia, Pemerintah Australia dan PTTEP Australasia Masing-masing pihak telah melakukan pemetaan terhadap pencemaran yang terjadi. Berikut penulis mencoba merangkum beberapa data yang diperoleh dari Kementrian Lingkungan Hidup Republik Indonesia mengenai Perhitungan Total Klaim Ganti Rugi Pencemaran di Laut Timor (2010).

Peristiwa tumpahan minyak yang terjadi di ZEE Australia hingga melewati ZEE Indonesia diawali pada tanggal 21 Agustus 2009. Awalnya, terjadi ledakan di the Montara Well Head Platform yang berlokasi di blok West Atlas-Laut Timor perairan Australia, tepatnya pada posisi $12^{\circ} 41^{\prime}$ LS $124^{\circ} 32^{\prime}$ BT. Terjadi tumpahan minyak dengan estimasi tumpahan $2.000 \mathrm{barel} / \mathrm{hari}$ (318.000 liter/hari), yang berdampak pada kebocoran minyak (light crude oil) dan gas hydrocarbon.

Pada tanggal 31 Agustus 2009, butiran kecil minyak (small patches weathered oil) telah memasuki wilayah ZEE Indonesia pada posisi $11^{\circ} 50^{\prime} \mathrm{LS}$ $125^{\circ} 10^{\prime}$ BT. Jejak tumpahan minyak mentah tersebut (weathered light crude oil) memasuki sebagian kecil Zona Ekonomi Eksklusif Indonesia yang berbatasan dengan Zona Ekonomi Eksklusif Australia, pada tanggal 1 September 2009. Hal ini tertulis dalam 
surat resmi kedutaan Australia No. P053/2009 tertanggal 3 September 2010, yang ditujukan kepada kedutaan Indonesia.

Tanggal 14 September 2009, pemerintah Australia telah menempatkan drilling rig tambahan (west Triton) di dekat Montara well head platform yang akan memotong original well pada kedalaman $2.6 \mathrm{~km}$ di bawah permukaan laut dan melakukan injeksi heavy mud sebagai upaya menutup kebocoran.

Setelah dilakukan pemantauan udara (aerial surveillance), pada tanggal 21 September 2009, diperoleh informasi bahwa sebagian tumpahan minyak telah berada pada lokasi $51 \mathrm{mil}$ laut di tenggara pulau Rote (Rotendau) Indonesia. Dua hari kemudian, Australian Maritime Safety Authority (AMSA) melakukan langkah penanggulangan melalui operasi recovery, menggunakan oil boom dan Skimmer pada koordinat $11^{\circ} 29,75^{\prime} \mathrm{LS}$ dan $124^{\circ} 08,09^{\prime}$ BT, setelah melakukan penyemprotan dispersant menggunakan dua pesawat udara dan Oil Cintainment serta melakukan recovery dengan tiga kapal. Pada tanggal 1 Oktober 2009, pemerintah Australia mengundang Tim Ditjen Hubla-Kemhub untuk melakukan observsasi bersama ke lokasi tumpahan minyak.

Saat petugas kilang menyuntikkan lumpur ke dalam sumur Montara untuk menekan kebocoran tak terkendali dari 2.600 meter di bawah permukaan laut, terjadi kebakaran (1 November 2009). Kebocoran tersebut akhirnya dapat ditanggulangi pada tanggal 3 November 2009 pukul 17.15 waktu setempat. Bersamaan dengan keberhasilan ini, kebakaran pada Montara wellhead platform dan sekitar rig pengeboran West Atlas di Laut Timor berhasil dipadamkan.
Kebocoran yang terjadi menimbulkan dampak pencemaran pada Propinsi Nusa Tenggara Timur (NTT). Dampak pencemaran terbesar dirasakan oleh delapan kabupaten/kotamadya di NTT, yaitu: Kabupaten Kupang, Kotamadya Kupang, Kabupaten Rote Ndao, Kabupaten Timor Tengah Selatan, Kabupaten Timor Tengah Utara, Kabupaten Sumba Timur, Kabupaten Sabu Raijua, dan Kabupaten Belu.

\section{Rumusan Masalah}

Berdasarkan latar belakang masalah diatas, penulis dapat menarik suatu permasalahan yang akan dikaji dalam tulisan ini, yaitu : Bagaimanakah dampak pencemaran lingkungan laut terhadap Indonesia akibat tumpahan Minyak Montara di Laut Timor?

\section{Pembahasan \\ Para Pihak Yang Terkait dengan Kasus Minyak Montara}

Perlu untuk melakukan klarifikasi mengenai para pihak yang terlibat dalam Kasus Minyak Montara ini. Sebab, perusahaan minyak yaitu PTTEP Australasia, yang menyebabkan terjadinya ledakan di ladang minyak Montara bukanlah perusahaan milik Australia. PTTEP Australasia benama lengkap PTTEP International Limited (Company Profile PTTEP Australasia) merupakan operator sumur minyak Montara yang merupakan perusahaan Thailand yang memiliki hak operasional untuk kegiatan eksplorasi sumur minyak. Australia sendiri merupakan negara yang memiliki konsesi eksplorasi sumur minyak Montara yang kemudian menyerahkan hak nya kepada PTTEP Australasia. Dalam Kasus Minyak Montara ini, Australia sendiri juga merupakan korban, disebabkan tumpahan minyak yang cukup luas juga mencemari lingkungan laut Australia. 
Oleh karena itu, Pemerintah Indonesia dalam upayanya untuk menyelesaikan Kasus Minyak Montara ini melakukan komunikasi dengan dua pihak, yaitu Pemerintah Australia dan Pemerintah Thailand.

Komunikasi yang dilakukan dengan Pemerintah Australia guna mendapatkan informasi yang jelas mengenai proses penanggulangan dan dampak yang terjadi di masing-masing negara. Komunikasi yang dilakukan oleh pemerintah Indonesia adalah dengan mengirimkan Tim Kementerian Perhubungan ke Darwin Australia sebagai focal point seperti yang disebutkan dalam $M o U$ Oil Pollution Preparedness and Response 1996 antara Indonesia-Australia. Komunikasi intergovermental antara Pemerintah Indonesia dengan Pemerintah Thailand dan antara Pemerintah Australia dengan Pemerintah Thailand dilakukan dikarenakan PTTEP adalah perusahan milik Thailand yang sebagian sahamnya dimiliki oleh Thailand. Tindakan yang dilakukan dalam komunikasi intergovermental adalah dengan mengajukan klaim ganti rugi kepada PTTEP Australasia. Klaim Pemerintah Indonesia kepada PTTEP Australasia berujung pada ganti rugi dengannilai sebesar \pm Rp. 291 miliar atau setara dengan \pm US\$ 30 juta (Report of the Incident Analysis Team;2010).

Atas klaim Pemerintah Indonesia kepada PTTEP Australasia ini, PTTEP Australasia beranggapan tidak terjadi kerusakan lingkungan di wilayah perairan Indonesia akibat tumpahan minyak Montara. Pandangan PTTEP Austalasia ini didasarkan pada penelitian yang menyatakan bahwa tidak ada bukti yang menunjukkan 1. Secara umum bahwa rantai karbon yang ringan akan mudah menguap di alam, namun sangat toksik terhadap kehidupan di laut dan mudah adanya minyak dari sumur Montara di sepanjang garis pantai pulau Timor dan pulau Rote. Karena sebagian besar wilayah yang terdampak oleh minyak Montara berada dalam radius $82 \mathrm{~km}$ dari sumur Montara dan tumpahannya sebagian besar ditahan dalam Zona Ekonomi Eksklusif (ZEE) Australia.

Pemerintah Australia juga mengumumkan bahwa tumpahan minyak Montara tidak mencemari perairan Indonesia, dimana 98,6 persen wilayah pencemaran minyak Montara berada di perairan Australia. Penelitian mengenai penggunaan dispersan juga merupakan prosedur normal untuk menanggulangi tumpahan minyak skala besar dengan tujuan mencegahatau meminimalisir minyak di permukaan mencapai garis pantai, dimana minyak yang dilarutkan tidak tenggelam ke dasar laut tetapi akan tertahan di kolom air antara 10 sampai 20 meter dibawah permukaan air laut. Sehingga dapat disimpulkan dari penelitian tersebut bahwa menurut AMSA dan PTTEP tidak terjadi kerusakan lingkungan di wilayah perairan Indonesia akibat tumpahan minyak Montara (Report of the Incident Analysis Team;2010).

\section{Dampak Pencemaran Minyak di Laut Timor}

Pada analisis GC, hasil chromatogram menunjukkan bahwa tarball yang ditemukan di Perairan ZEE Indonesia mengandung minyak mentah (crude oil) yang memiliki karakteristik yang sama dengan contoh minyak yang berasal dari Montara Wellhead Platform. Minyak yang ditemukan di Perairan Indonesia memiliki rantai C13C34 yang memiliki sifat-sifat:

terdegradasi. Minyak mentah ringan (light crude oil) mengandung $2-20 \%$ komponen aromatik ringan dimana 
heavy crude oil mengandung sampai $2 \%$.

2. Rantai karbon 10 sampai 24 (C10-C24) biasanya mudah untuk mengalami metabolisme.

3. Rantai C29 dengan cabang alkana biasanya lebih sulit mengalami biodegradasi dari pada alkana normal (n-alkana) tapi lebih mudah mengalami biodegradasi dibandingkan normal cycloalkana (naphthenes).

4. Rantai C30 dengan cabang alkana tahan terhadap mikroba pengurai. Semakin meningkat jumlah alkana semakin resist.

5. Rantai C32 memiliki karakteristik paling sedikit 1 ring benzene.

6. Rantai C33 sejalan dengan meningkatnya jumlah molekul dan kompleksitas, kandungan aromatik hanya mengalami sedikit degradasi di alam. Sehingga tingkat degradasi dari polyaromatics akan lebih lambat dibanding monoaromatics. Aromatik dengan 5 hingga 6 ring tidak mudah untuk terurai di lingkungan dan akan bertahan dalam jangka waktu lama.

7. Rantai C34 biasanya hanya mengandung $2-10 \%$ minyak ringan dan 35\% minyak berat.

Dapat disimpulkan bahwa minyak yang ditemukan di Perairan Indonesia memiliki kandungan jenis minyak ringan dan berat. Pada rantai karbon yang tinggi akan sulit terdegradasi di lingkungan laut dan akan bertahan pada periode waktu yang lama.

Dengan tingginya nilai TPH (T1, T2, dan T3) yaitu antara 705,100 hingga 932,800 ppm sangat membahayakan kehidupan di laut. Sementara temuan di Montara Wellhead Platform menunjukan nilai PAH yang mencapai 93,200 ppm. Menurut Peterson (2001), dampak TPH pada jangka waktu lama akan mengganggu reproduksi dan berdampak kepada penurunan populasi dari individu/spesies penting tertentu di alam yang akan menganggu fungsi ekosistem.

Gambar : Perubahan Sifat Fisik Minyak Di Laut Saat Terjadi Pencemaran

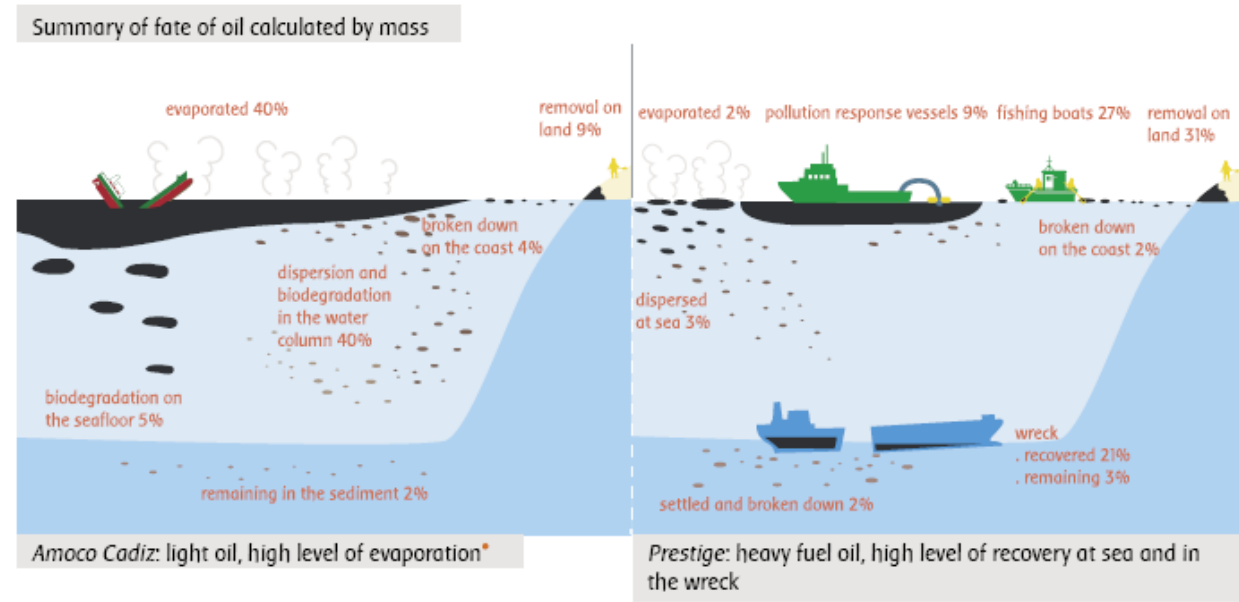

(sumber: Tim Observasi terpadu-KLH).

Berdasarkan contoh kejadian tumpahan minyak Amoco Cadiz dan Prestige, dapat disimpulkan bahwa sebagian minyak akan terlarut di laut dengan presentasi $3-40 \%$. Hal ini mengindikasikan bahwa walau secara kasat mata minyak sudah tidak terlihat, akan tetapi pada prosentase tersebut minyak menyatu dengan air laut (terlarut). Sehingga dari besar kemungkinan minyak yang terlarut di perairan akan terbawa arus hingga sampai di pantai yang dibuktikan 
dengan tingginya nilai PAH di Pantai Nusa Tenggara yaitu mencapai 213 ppm pada Bulan Mei 2010. Berdasarkan arah angin dan arus permukaan menunjukan yaitu bahwa angin dan arus pada bulan oktober 2009 menunjukan bahwa arah menuju NTT.

Uji dispersan menunjukan bahwa percampuran dispersan dengan minyak memiliki sifat yang lebih toksik bila dibandingkan dengan minyak yang tidak dicampur dispersan. Hal ini ditunjukan oleh penggunaan dispersan dengan jenis dagang Corexit@EC9500A dan Corexit@EC9527A yang ternyata bersifat toksik dan membunuh.

Ditemukannya korelasi antara minyak yang ada di Montara dengan minyak yang ditemukan di perairan Indonesia, menyebabkan terganggunya ekosistem dan perairan di laut Timor yang berdampak pada Wilayah Pengelolaan Perikanan (WPP) seluas $70.841,76 \mathrm{~km}^{2}$, Taman Nasional Laut Sawu seluas $34.089,87 \mathrm{~km}^{2}$, pengembangan daerah perikanan seluas $135.799,93 \mathrm{~km}^{2}$, wilayah distribusi dugong (duyung) seluas $15.712,11 \mathrm{~km}^{2}$, wilayah distribusi kura-kura laut seluas $4.096,40 \mathrm{~km}^{2}$, dan wilayah terumbu karang seluas $944,90 \mathrm{~km}^{2}$.

Tingginya PAH di perairan laut Timor menimbulkan toksik pada telur ikan pada konsentrasi 0,5 - 10 ppm, pertumbuhan abnormal pada kepiting dan larva barnacle pada konsentrasi 10 - $100 \mathrm{ppb}$, dan bersifat toksik pada juvenile copepods pada konsentrasi 1 ppb. Konsentrasi TPH yang lebih besar dari 200 - 300 ppm pada organisme laut, maka akan menurunkan nilai jual. Sementara nilai TPH di perairan laut Timor tercemar tumpahan minyak dengan kandungan nilai TPH 705,100 932,800 ppm.

\section{Kerugian Sosial Ekonomi dan Dampak Lingkungan}

Kerugian sosial ekonomi dan dampak lingkungan merupakan akibat dari terganggunya lingkungan perairan akibat tumpahan minyak yang berdampak kepada penurunan hasil perikanan tangkap, terganggunya kenyamanan penduduk di pesisir, penurunan hasil tangkap ikan karang, terganggunya rumput laut (penurunan produksi dan kematian), terganggunya ekosistem (terumbu karang, mangrove, dan padang lamun) yang merupakan tempat ikan dan biota laut lainnya memijah dan membesarkan anak ikan (spawning-nursery ground), terganggunya fungsi fisik mangrove dan terumbu karang yang mempunyai fungsi sebagai penyedia jasa lingkungan.

\begin{tabular}{llr}
\multicolumn{2}{c}{ Perhitungan nilai } & kerugian \\
ekonomi & ekologi & dilakukan \\
menggunakan & analisis & regresi, yang \\
meliputi : & &
\end{tabular}
meliputi :

a. Penilaian kerugian lingkungan perairan dengan teknik EOP terhadap nilai ekonomi ekologi sumberdaya perikanan, yaitu dengan menilai kemungkinan kerugian produktivitas lingkungan perairan akan sumberdaya ikan pelagis dan demersal. Potensi kerugian nilai ekonomi yang didekati dengan perhitungan net present value (NPV) sepanjang dua tahun terhitung sebesar Rp 11.443.455.251.939,10.

b. Penilaian kerugian lingkungan pantai dengan teknik CVM terhadap nilai ekonomi ekologi kawasan pantai, yaitu dengan menilai kemungkinan kerugian atas nilai estetika keberadaan lingkungan pantai. Potensi kerugian nilai ekonomi yang didekati dengan perhitungan 


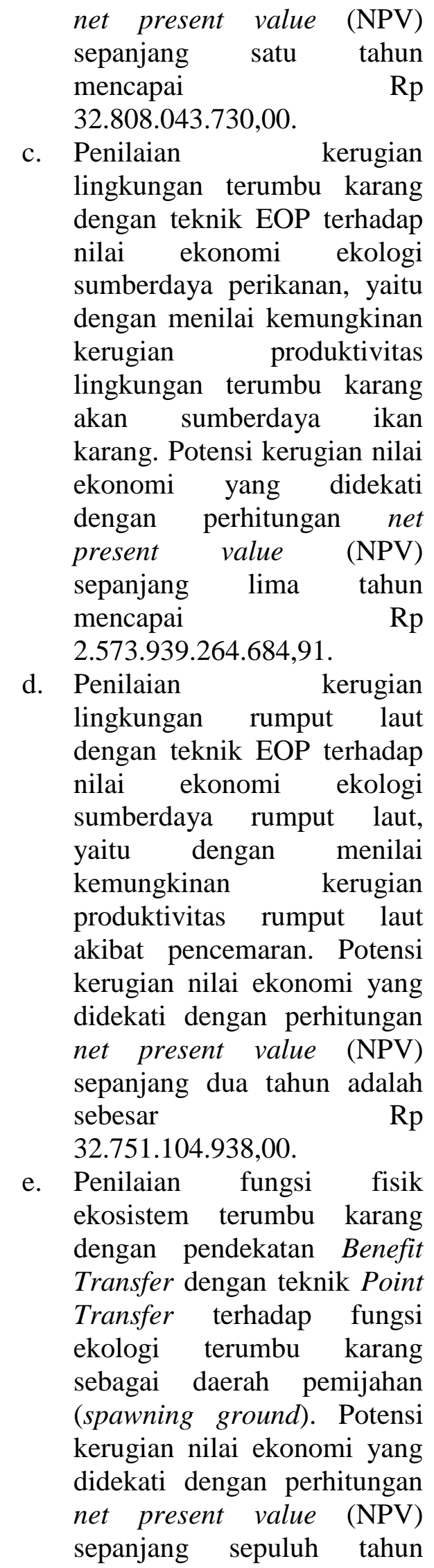

menccapai Rp

9.252.108.339,80.

f. Penilaian fungsi fisik

ekosistem padang lamun dengan pendekatan Benefit Transfer dengan teknik Point Transfer terhadap produktivitas primer. Potensi kerugian nilai ekonomi yang didekati dengan perhitungan net present value (NPV) sepanjang dua tahun adalah sebesar Rp 33.889.444.667,14.

g. Penilaian fungsi fisik ekosistem hutan mangrove dengan pendekatan Benefit Transfer dengan teknik Point Transfer terhadap fungsi ekologi hutan mangrove sebagai persediaan karbon (carbon stock) dan sebagai manfaat pilihan keanekaragaman hayati. Potensi kerugian nilai ekonomi yang didekati dengan perhitungan net present value (NPV) sepanjang sepuluh tahun adalah sebesar Rp 409.255.688.673,17 yang terdiri atas $\mathrm{Rp}$ 407.865.238.994,78 manfaat persediaan karbon dan $\mathrm{Rp}$ 1.390.449.678,39 manfaat biodiversitas.

Dari uraian di atas, diperoleh nilai kerugian ekonomi ekologi total berdasarkan lama dan sebaran dampak. Perhitungan estimasi total sebesar Rp 14.050.145.621.561,90 didasarkan pada asumsi sebagai berikut:

a. Sebaran dampak diperoleh dari hasil modelling dengan asumsi bahwa dampak terdistribusi merata pada kawasan yang terkena. 
b. Lamanya dampak yang berlangsung diperoleh dari hasil modelling dan penelitian sebelumnya tentang lamanya kontaminan berada pada sumberdaya tanpa adanya rehabilitasi.

c. Lama dampak diasumsikan linier dengan nilai kerugian.

d. Sebaran dampak diasumsikan linier dengan nilai kerugian.

\section{Simpulan}

Dari hasil penelitian ini, maka penulis dapat menyimpulkan, antara lain : bahwa menurut Pemerintah Republik Indonesia, Kasus Minyak Montara yang terjadi di Laut Timor juga berakibat pada wilayah perairan Indonesia khususnya di wilayah Provinsi Nusa Tenggara Timur. Hanya

\section{Daftar Pustaka}

R.R.Churchill and A.V.Lowe, 1999, The Law of the Sea, New York, Juris Publishing, hlm. 328.

Lihat : Company Profile PTTEP Australasia, http://www.securities.com/Publi c/companyprofile/TH/PTTEP_In ternational_Limited_en_210279 0.html . Diakses pada tanggal 09 Agustus 2012.

Report of the Incident Analysis Team, Response to the Montara Wellhead Platform Incident, 2010, Australian Maritime Safety Authority

Light Crude Oil adalah minyak dengan gravitasi di bawah 28 derajat API(Gravitasi API adalah skala sembarang mengekspresikan gravitasi atau kepadatan produk minyak bumi cair dirancang saja, PTTEP Australasia, berdasarkan partnership research dengan beberapa perguruan tinggi di Australia, menyatakan bahwa dampak dari Kasus Minyak Montara tidak menimbulkan dampak negatif ke wilayah perairan Indonesia.

\section{Saran}

Berdasarkan kesimpulan diatas, penulis dapat memberikan saran sebagai berikut : sebaiknya dibentuk suatu konvensi internasional atau aturan hukum internasional yang khusus berkaitan dengan pencemaran lingkungan laut akibat pengeboran minyak lepas pantai. Seperti contohnya MARPOLyang khusus mengatur mengenai pencemaran minyak dari kapal.

bersama oleh American Petroleum Institute dan Badan Standar Nasional. Skala pengukuran dikalibrasi dalam hal API derajat. Lihat : www.trencome.com ), Canadian Association of Petroleum Procedurs, www.capp.ca . Diakses pada tanggal 09 Agustus 2012.

Heavy Crude Oil adalah cairan minyak bumi yang memiliki kepadatan rendah dan mengalir dengan bebas pada suhu kamar. Minyak berat adalah, dengan konvensi, biasanya 9,0-11 API derajat. Lihat : Canadian Association of Petroleum Procedurs, ibid. Diakses pada tanggal 09 Agustus 2012. 